\title{
Extrusion of blends of Cassava Leaves and Cassava Flour: physical characteristics of extrudates
}

\author{
Cristiane da Cunha SALATA ${ }^{1}$, Magali LEONEL ${ }^{1 \star}$, Fernanda Rossi Moretti TROMBINI ${ }^{1}$, Martha Maria MISCHAN ${ }^{2}$
}

\begin{abstract}
A cassava-based puffed snack was produced using a single screw extruder to determine the effect of the raw material composition (cassava leaf flour and moisture) and the process parameters (extrusion temperature and screw speed) on the physical characteristics of an extruded-expanded snack. A central composite rotational design, including four factors with 30 treatments, was used with the following as dependent variables: expansion index, specific volume, water solubility index, water absorption index, color $\left(\mathrm{L}^{*}, \mathrm{a}^{*}, \mathrm{~b}^{*}\right)$, and hardness. Under conditions of low moisture content (12 to $\left.14 \%\right)$, low percentage of cassava leaf flour ( 2 to $4 \%)$, and intermediate conditions of extrusion temperature $\left(100^{\circ} \mathrm{C}\right)$ and screw speed $(230 \mathrm{rpm})$, it was possible to obtain puffed snack products with desirable characteristics.
\end{abstract}

Keywords: leaves; cassava; puffed snacks.

\section{Introduction}

Extrusion cooking, such as multi-step, multi-functional, and thermal/mechanical processes, has enabled a large number of food applications. It is a food process in which ingredients are subjected to mixing, heating and shearing, and are forced to flow through a die that forms and expands the ingredients. Effects of extrusion cooking on nutritional quality include changes in proteins and amino acid profile, carbohydrates, dietary fiber, vitamins, mineral content, and some non-nutrient healthful components of food, which may be beneficial (Singh et al., 2007b).

The basic structures of extruded products are formed by transforming and manipulating natural biopolymers, such as those of starch or of certain types of proteins. In the former case, the most commonly used materials are the cereals; however, other starch-rich materials, such as cassava, can be used.

Cassava's importance in agriculture has changed dramatically. Between 1980 and 2011, the global harvested area of cassava expanded by 44 percent, from 13.6 million to 19.6 million hectares, which was the biggest percentage increase among the world's five major food crops. In that same period, world cassava production more than doubled, from 124 million to 252 million tons (Food and Agriculture Organization of the United Nations, 2013).

Growing populations in the cassava-producing countries will continue to provide a home market for cassava roots and products. Many countries have started producing it, and the international market for many products has become more competitive (Food and Agriculture Organization of the United Nations, 2013). Cassava has the potential to make a much more important contribution to economy and can be used to make a variety of food products, for both local consumption and export, if cassava products can compete with other raw materials containing starch.
In Brazil, the products made from cassava vary widely from region to region, but flour is the most common. The industrial sector of cassava processing is now seeking access to new markets, either through creating new uses for cassava derivatives or through the development of new products.

Cassava leaves are regularly picked and cooked for human consumption in several countries. The tender leaves contain up to 25 percent protein, on a dry matter basis, and are a valuable source of iron, calcium, and vitamins A and C. The essential amino acid content of cassava leaf protein is similar to that found in a hen's egg. The market value of cassava leaves in areas where they are consumed is often higher than that of the roots, indicating that their sale contributes significantly to farm household incomes (Chavez et al., 2000, Howeler, 2012, Food and Agriculture Organization of the United Nations, 2013).

A large amount of cassava leaves is wasted during root harvest in all regions of Brazil. It is estimated that for an area of 158 million hectares, more than 178,000 tons of leaves are wasted each year. Based on the number of leaves produced per plant per hectare, it is possible to obtain approximately $2.250 \mathrm{~kg}$ of cassava leaf flour per hectare (Sagrilo et al., 2001). One option for use this waste would be to produce flour, which can be used as a new raw material for extrudates.

An advantage of extrusion cooking of cassava leaves can be the destruction of antinutritional factors, especially trypsin inhibitors, hemaglutinins, tannins, and phytates; all of which inhibit protein digestibility (Arêas, 1992; Singh et al., 2007b).

Despite the wide use of extrusion in the development of food products, the use of derivatives of cassava as raw material has yet been unusual. Thus, in this study, the effects of process parameters and blends of leaves and cassava flour on the physical 
properties of snacks were evaluated aiming at enhancing the use of derivatives of cassava in the production of puffed snacks.

\section{Materials and methods}

The raw materials used in this study included industrial cassava flour (Plaza Ind. Alim. Ltda, Santa Maria da Serra-SP, Brazil) and cassava leaf flour.

To produce cassava leaf flour, cassava leaves harvested 12 months after cassava planting were washed with water. The leaves were dried in an oven with air circulation at a temperature of $50^{\circ} \mathrm{C}$ for $24 \mathrm{~h}$. After drying, the material was ground using a knife mill (MA680 - Marconi, Brazil) to obtain the flour.

Industrial cassava flour showed $12.6 \%$ of moisture, $0.75 \%$ of ash, $1.14 \%$ of crude fiber, $0.22 \%$ of lipids, $0.33 \%$ of protein, and $75.02 \%$ of total carbohydrates. Cassava leaf flour showed $9.09 \%$ of moisture, $5.96 \%$ of ash, $25.78 \%$ of crude fiber, $13.9 \%$ of lipids, $22.95 \%$ of protein, and $21.11 \%$ of total carbohydrates.

Cassava flour and cassava leaf flour mixtures were prepared, and moisture content was adjusted to the experimental design. After homogenization in a "Y" TE201/5 homogenizer (Tecnal, São Paulo, Brazil) for $5 \mathrm{~min}, 20$ samples of $1 \mathrm{~kg}$ were set aside.

Extrusion was carried out using a complete line of Inbra RX50 (Inbramaq, São Paulo, Brazil), which has a motor coupled with a speed reducer (extrusion by mechanical friction), a single extrusion screw, $130 \mathrm{~mm}$ barrel diameter, $440 \mathrm{~mm}$ extruder length, a hydraulic cooling system for temperature control, variable speed, and a $50 \mathrm{~kg} \mathrm{~h}^{-1}$ capacity.

The extrusion process parameters were:

- Constant parameters: extrusion temperature in the $1^{\text {st }}(20$ to $25^{\circ} \mathrm{C}$ ) and $2^{\text {nd }}$ zones ( 40 to $45^{\circ} \mathrm{C}$ ); screw compression ratio (3:1); screw diameter $(32,6 \mathrm{~mm})$, die diameter (3 $\mathrm{mm})$; feed rate $\left(150 \mathrm{~g} \mathrm{~min}^{-1}\right)$; and cutting speed $(90 \mathrm{rpm})$.

- Variable parameters: cassava leaf flour amount, feed moisture; barrel temperature in the $3^{\text {rd }}$ zone; and screw speed (Table 1). The variation ranges between the upper and the lower limit of variables were established based on preliminary tests.

During the extrusion process, a portion of the next test material was used to purge the previous material from the extruder. A total of $500 \mathrm{~g}$ of extruded sample were collected after achieving steady-state flow in the extruder. The extruded samples were dried $\left(40^{\circ} \mathrm{C}\right)$ to the desired moisture $(6-7 \%)$ in an oven with air circulation (Marconi - MA037 Brazil). Each dried samples was divided into two portions and stored in plastics bags hermetically sealed until evaluation. A portion of each sample was powdered using a knife mill (Marconi-MA 680, Brazil) with screen of $468 \mathrm{~mm}$.

The expansion index (EI) of the snacks was evaluated after extrusion and before drying. It was determined using a digital caliper. Expansion indexes are derived from the division of radial expansion by the die orifice diameter $(3.0 \mathrm{~mm})$. The value considered was the arithmetic mean of the measurements of 20 different expanded products in each treatment (Faubion \& Hoseney, 1982).

Specific volume (SV) of snacks was determined according to the mass displacement method (millet seed) using a graduated cylinder.

Water absorption index (WAI) and water solubility index (WSI) were assessed before and after the extrusion process (Anderson et al., 1969). The extrudates were ground to a mean particle size of approximately $150 \mu \mathrm{m}$. A $2.5 \mathrm{~g}$ sample was dispersed in $25 \mathrm{~g}$ distilled water using a glass rod to break up any lumps. After stirring for $30 \mathrm{~min}$, the dispersions were rinsed into tared centrifuge tubes, made up to $32.5 \mathrm{~g}$, and centrifuged at $5000 \mathrm{rpm}$ for $10 \mathrm{~min}$. The water absorption index (WAI) is the weight of gel obtained per gram of dry ground sample. The water solubility index (WSI) is the percentage of dry matter recovered after the supernatant is evaporated from the water absorption determination. WAI and WSI were calculated as follows:

WAI $=\frac{\text { Weighto of Sediment }}{\text { Weight of Dry Solids }} \quad$ WSI $=\frac{\text { Weight of Dissolved Solids in Supernatant } \times 100}{\text { Weight of Dry Solids }}$

Color measurements (CIE L $L^{*}, a^{*}, b^{*}$ color space) were performed on the raw materials before extrusion and on the ground extruded samples using a Minolta CR-400 model colorimeter (Konica Minolta, Ramsey, NJ, USA). The color of extrudates was expressed as the average of three $L^{*}, a^{*}$, and $\mathrm{b}^{*}$ readings, where $\mathrm{L}^{*}$ stands for brightness, $+\mathrm{a}^{*}$ redness, $-a^{*}$ greenness, $+b^{\star}$ yellowness, and $-b^{*}$ blueness. A white calibration tile was used to calibrate the equipment prior to color measurements.

The hardness of samples was determined using a texture analyzer TA-XT2 (Stable Micro Systems, Surrey, England) with a $5 \mathrm{Kg}$ load cell and a HDP/WBV probe (Warner Bratzler set with "V" slot blade for USDA Standard) with test speed of $1 \mathrm{~mm} / \mathrm{s}$. The cut was performed perpendicularly to the main axis of the snack until breaking it completely. The maximum value of force obtained, expressed in Newtons, was considered as the result of the test. For each treatment, ten extrudates were assayed.

Response Surface Methodology describes the behavior of a system in which the independent variables $\left(\mathrm{X}_{\mathrm{k}}\right)$ and the

Table 1. Process variables used in the central composite design for four independent variables.

\begin{tabular}{lccccc}
\hline \multirow{2}{*}{ Independent variables } & \multicolumn{3}{c}{ Levels of variation } \\
\cline { 2 - 6 } & $-<$ alpha $>$ & -1 & 0 & +1 & $+<$ alpha $>$ \\
\hline Cassava leaf flour (\% wet basis) & 2 & 4 & 6 & 10 & 245 \\
Screw speed (rpm) & 200 & 215 & 230 & 110 & 100 \\
Extrusion temperature $\left({ }^{\circ} \mathrm{C}\right)$ & 80 & 90 & 16 & 18 & 20 \\
Moisture (\%) & 12 & 14 & 100 & 20 \\
\hline
\end{tabular}


dependent variable or response $\left(\mathrm{Y}_{\mathrm{i}}\right)$ are combined. The response is a function of the levels at which those factors were combined and defined.

Within the proposed variation ranges, i.e. within the region characterized by these levels, the behavior of each response can be predicted in a general form according to the equation:

$Y_{1}=\beta_{0}+\beta_{1} X_{1}+\beta_{2} X_{2}+\beta_{3} X_{3}+\beta_{4} X_{4}+\beta_{11} X_{1}{ }^{2}+\beta_{22} X_{2}{ }^{2}+\beta_{33} X_{3}{ }^{2}+\beta_{44} X_{4}{ }^{2}+$ $\beta_{12} X_{1} X_{2}+\beta_{13} X_{1} X_{3}+\beta_{14} X_{1} X_{4}+\beta_{23} X_{2} X_{3}+\beta_{24} X_{2} X_{4}+\beta_{34} X_{3} X_{4}+\beta$

Where:

$\mathrm{Y}_{1=}$ Dependent variable or response function;

$\mathrm{X}_{1}, \mathrm{X}_{2}, \mathrm{X}_{3}, \mathrm{X}_{4}=$ Values of the independent variables;

$\beta_{\mathrm{o}}=$ Coefficient relative to the line interception with the response axis;

$\beta_{1}, \beta_{2}, \beta_{3}, \beta_{4}=$ Linear coefficients assessed through least square method;

$\beta_{11}, \beta_{22}, \beta_{33}, \beta_{44}=$ Coefficients of quadratic variables;

$\beta_{12}, \beta_{13}, \beta_{14}, \beta_{23}, \beta_{24}, \beta_{34}=$ Coefficients of interaction between independent variables;

$\varepsilon=$ Experimental error.

The model was fitted by the stepwise selection of the SAS program (Statistical Analisys System Institute, 2004); the model obtained was validated by the F-test using the pure error mean square as denominator.

The response surface plots were drawn based on the adjusted models using the software Statistica ${ }^{\circledR} 7.0$ (STATSOFT, 2004).

\section{Results and discussion}

The blends of raw materials were characterized before the extrusion process, and the color analysis of blends showed that brightness ranged from 80.88 to 73.00 , the presence of $-\mathrm{a}^{\star}$ in blends of high percentage of cassava leaf flour $(0.42$ to -0.38$)$, and the presence of $+b^{*}$ (13.79 to 11.72$)$ in all blends.

The water absorption index (WAI) of the mixtures ranged from 4.85 to 5.93 g.gel.g- ${ }^{-1}$. The highest values were observed in the mixtures with lower percentage of cassava leaf flour. The WSI of the mixtures, which measures the total degree of degradation of the starch granule, ranged from 1.40 to $2.92 \%$. The highest WSI was obtained in the blends with lower content of cassava leaf flour, which can be due to the high content of other components in this flour, mainly protein.

Table 2 summarizes the estimated regression coefficients for the models fitted to the experimental results and their significance, as well as their corresponding coefficients of determination.

The expansion index ranged from 2.69 to 3.75. Data analysis showed negative quadratic effects of cassava leaf flour and moisture on this parameter, as well as an interaction effect of these parameters (Table 2). Higher expansion index can be obtained under intermediate conditions of cassava leaf flour and moisture (Figure 1).

The degree of expansion of an extruded product is closely related to the size, number, and distribution of air cells surrounded by the cooked material. High pressure close to the discharge of the die is reduced when the products leave the extruder causing flash evaporation of water and expansion of the product.

Table 2. Regression equation coefficients of fitted models.

\begin{tabular}{|c|c|c|c|c|c|c|c|c|}
\hline & EI & SV & WSI & WAI & $\mathrm{L}^{*}$ & $a^{*}$ & $b^{*}$ & $\mathrm{H}$ \\
\hline Intercept & 3.63 & 6.15 & 62.61 & 7.84 & 58.20 & 1.16 & 20.62 & 15.46 \\
\hline LF & ns & ns & $5.05^{\star}$ & ns & $-2.41^{\star * *}$ & $-0.28^{\star *}$ & ns & ns \\
\hline $\mathrm{T}$ & ns & ns & ns & ns & ns & ns & $-0.27^{\star}$ & $3.32^{*}$ \\
\hline M & ns & $-1.63^{\star * *}$ & ns & $0.89^{* * *}$ & $-1.45^{\star \star}$ & $-0.37^{\star * *}$ & ns & ns \\
\hline SS & ns & ns & $-5.25^{\star}$ & ns & ns & ns & ns & ns \\
\hline $\mathrm{LF}^{\star} \mathrm{LF}$ & $-0.15^{\star \star}$ & ns & ns & ns & ns & $0.28^{\star *}$ & $-0.32^{* *}$ & ns \\
\hline $\mathrm{T}^{\star} \mathrm{T}$ & ns & $-0.34^{\star}$ & ns & ns & ns & $0.27^{\star *}$ & ns & ns \\
\hline $\mathrm{M}^{*} \mathrm{M}$ & $-0.13^{\star *}$ & ns & ns & ns & ns & $0.17^{\star}$ & ns & ns \\
\hline $\mathrm{SS}^{*} \mathrm{SS}$ & ns & $-0.42^{\star *}$ & ns & ns & ns & ns & ns & ns \\
\hline $\mathrm{LF}^{*} \mathrm{~T}$ & ns & ns & ns & ns & ns & $0.29^{\star *}$ & ns & ns \\
\hline $\mathrm{LF}^{\star} \mathrm{M}$ & $0.18^{\star *}$ & ns & ns & ns & ns & $0.29^{* *}$ & ns & ns \\
\hline $\mathrm{LF}^{\star} \mathrm{SS}$ & ns & $-0.63^{* * *}$ & ns & ns & ns & ns & ns & ns \\
\hline $\mathrm{T}^{*} \mathrm{M}$ & ns & ns & ns & ns & ns & ns & ns & ns \\
\hline $\mathrm{T}^{\star} \mathrm{SS}$ & ns & ns & ns & ns & ns & ns & ns & $-4.04^{\star}$ \\
\hline$M^{*} S S$ & ns & ns & ns & ns & ns & ns & ns & ns \\
\hline $\mathrm{R}^{2}$ & 0.71 & 0.90 & 0.53 & 0.45 & 0.82 & 0.85 & 0.62 & 0.54 \\
\hline F value & 2.60 & 9.76 & 1.19 & 0.87 & 5.18 & 5.88 & 1.69 & 1.25 \\
\hline $\operatorname{Pr}>\mathrm{F}$ & 0.03 & $<0.0001$ & 0.37 & 0.59 & 0.001 & 0.0008 & 0.16 & 0.33 \\
\hline
\end{tabular}

$\mathrm{LF}=$ cassava leaf flour; $\mathrm{SS}=$ screw speed; $\mathrm{T}=$ temperature; $\mathrm{M}=$ moisture; $\mathrm{ns}=$ non-significant; ${ }^{*}=\mathrm{P}<0.05,{ }^{* *}=\mathrm{P}<0.01,{ }^{* * *}=\mathrm{P}<0.001 ; \mathrm{EI}=\mathrm{expansion}$ index; $\mathrm{SV}=$ specific volume; $\mathrm{WSI}=$ water solubility index; WAI $=$ water absorption index; $\mathrm{L}^{*}=$ brightness $\mathrm{a}^{*}=$ redness or greenness; $\mathrm{b}^{*}=$ yellowness or blueness; $\mathrm{H}=\mathrm{Hardness}$. 

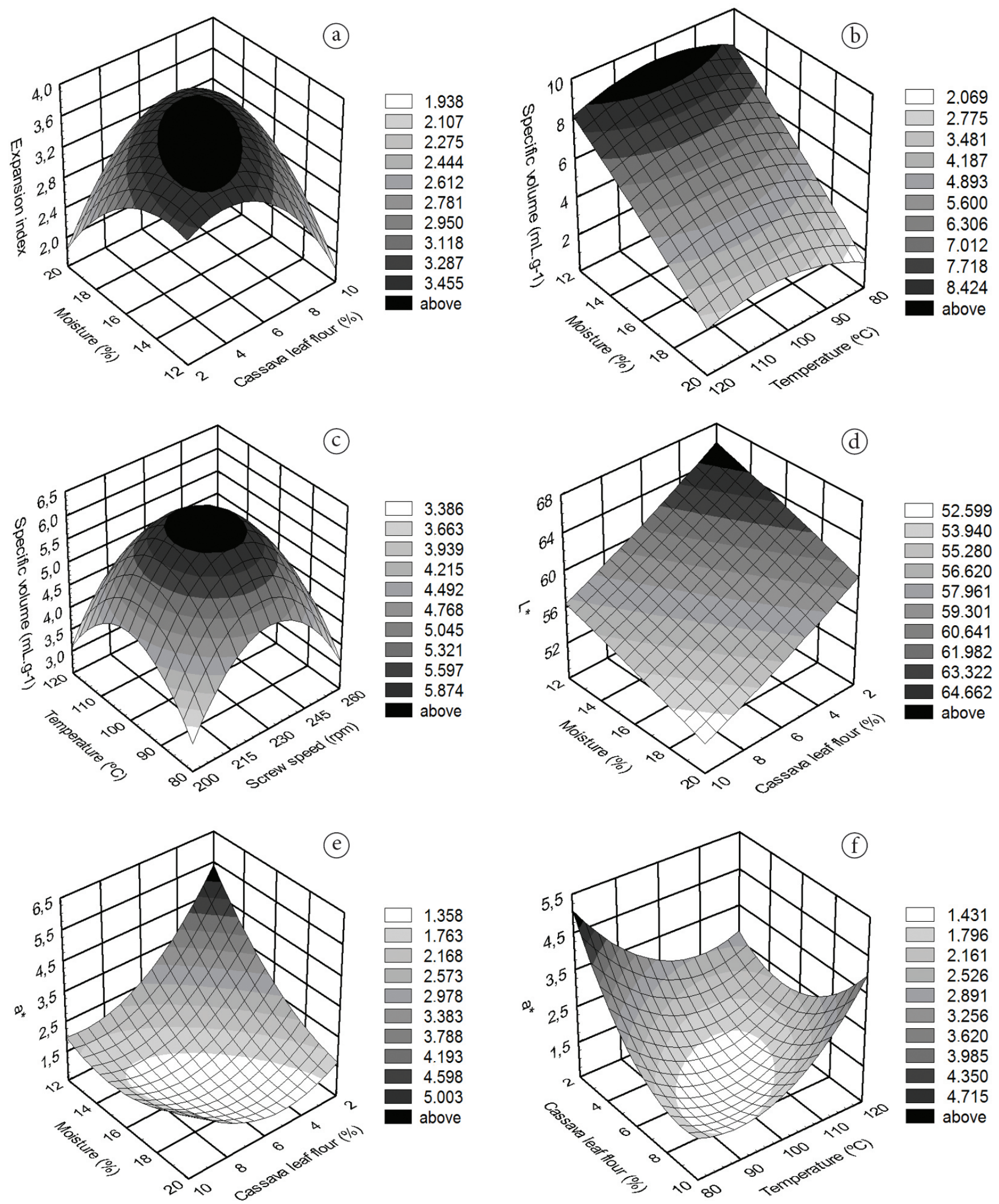

Figure 1. Effects of extrusion parameters on expansion index (a), specific volume (b, c), $L^{*}(d)$, and $a^{\star}$ value (e, f) of extruded products. 
The effect of moisture on expansion has been related. Foods with lower moisture tend to be more viscous than those with higher moisture; therefore, the pressure differential would be smaller in higher moisture foods, leading to a less expanded product (Singh et al., 2007a).

At higher moisture levels there is more moisture available for steam formation and expansion of the starch. This higher moisture content may also reduce the viscosity of the extrudate making it less resistant to expansion by the steam. The lower viscosity and greater capacity for steam formation may combine to form more cells with thinner cell walls producing an extrudate highly susceptible to the rupturing of cells and collapse of the cellular structure.

The high contents of protein and fiber of cassava leaf flour may have affected the expansion. While starch plays a major role in expansion, other ingredients (proteins, sugars, fats, and fibers) act as diluents, and the maximum expansion has been observed in pure starch (Moraru \& Kokini, 2003).

In general, as the amount of protein in the extrudates increased, expansion ratio decreased. When an amylose-protein complex is present, reduced radial expansion could be expected due to the combination of a reduced tendency to expand radially and an increased susceptibility to elastic recoil. Fibers also affect the expansion of the product. Fibrous fragments disrupt the starchy film of air cell walls, reducing their formation and swelling and altering air cell size (Huber, 2001; Allen et al., 2007).

Specific volume is a key performance parameter for extruded puffed snacks. It is a measurement of volumetric expansion, which is the sum of radial and axial expansions. The specific volume of extruded products ranged from 1.80 to 8.71 $\mathrm{mL} . \mathrm{g}^{-1}$, with values close to the average specific volume $(8.72$ mL. $\mathrm{g}^{-1}$ ) of commercial corn snacks, as reported by Alves \& Grossmann (2002). The results of this experiment were similar to those found by Trombini et al. (2013), who observed specific volume ranging from 2.64 to $7.75 \mathrm{ml} . \mathrm{g}^{-1}$ in snacks of blends of soy flour, cassava starch, and cassava bran.

The analysis of the regression coefficients showed negative effects of moisture, temperature screw speed, and interaction of leaf flour and moisture on specific volume (Table 2). The fitted model can be considerably predictive (Lack of fit $p>0.05$ ). With significant probability values $(\mathrm{p}<0.001)$ and non-significant lack of fit, models could be adequately used as predictor models (Yagci \& Gogus, 2008).

Higher specific volumes are obtained under conditions of low moisture and intermediate extrusion temperature and screw speed (Figure 1). The negative effect of moisture on specific volume can be due to the fact that blends with lower moisture tend to be more viscous than those with higher moisture and, therefore, the pressure differential would be smaller for higher moisture foods, leading to a less expanded product (Singh et al., 2007b).

Volume expansion phenomena are basically dependent on viscous and elastic properties of melted dough. When temperature increases, melt viscosity is reduced and axial expansion increases.
The increase in the screw speed may have decreased the melt viscosity of the dough mass because of increased shear, and resulted in a decrease of expansion.

Water solubility index (WSI) and water absorption index (WAI) are indices related to the estimation of the behavior of the extruded material when it is processed for use as a binder, a stabilizer, or a source of protein in beverages, protein bars and nutrition bars, bakery and dairy products, and emulsified or ground meats (Oikonomou \& Krokida, 2012).

The values obtained for the water solubility index of the extruded products ranged from 30.79 to $70.25 \%$. Water solubility index (WSI), often used as an indicator of degradation of molecular components, depends on the intensity and type of reactions that occur during extrusion.

Statistical analysis showed linear positive effect of cassava leaf flour and negative effect of screw speed on this parameter (Table 2$)$. The model proposed was not significant $(\mathrm{p}>0.05)$, and it was not a predictive model (lack of fit $<0.05$ ).

In addition to starch gelatinization, which results in the release of amylose and amylopectin, dextrinization, and other reactions that lead to the formation of low molecular weight compounds can occur, influencing the WSI (Camire \& Krumhar, 1990).

Water absorption index (WAI) depends on the presence of relatively intact molecules which have not lost their ability to bind water after extrusion. The WAI of extruded products ranged from 4.82 to $10.89 \mathrm{~g}$ gel. $\mathrm{g}^{-1}$. The data analysis showed linear effect of moisture on this parameter, but the model was not significant.

Color is an important characteristic of extruded foods. Color changes can provide information about the extent of browning reactions such as caramelization, Maillard reaction, degree of cooking, and pigment degradation that take place during the extrusion process (Altan et al., 2008).

The results obtained for the brightness $\left(\mathrm{L}^{\star}\right)$ of extrudates ranged from 53.6 to 65.5 . The statistical analysis showed negative linear effect of the content of cassava leaf flour and moisture on brightness (Table 2). The fitted model can be considerably predictive (Lack of fit $p>0.05$ ).

Underconditions of low percentage of leaf flour and low moisture, the $\mathrm{L}^{*}$ value of the products was higher (Figure 1). Similar result was observed by Mesquita et al. (2013), who reported negative linear effect of flaxseed flour mixed with cassava sour starch on brightness.

The results obtained for the $\mathrm{a}^{*}$ value of the extruded products ranged from 0.77 to 3.24 . The analysis of the regression coefficients showed a negative linear effect of cassava leaf flour and moisture, a quadratic effect of cassava leaf flour, temperature, and moisture, and an interaction effect of leaf flour and temperature and moisture. Under conditions of low content of moisture and low cassava leaf flour and intermediate temperature, the $\mathrm{a}^{*}$ value is lower (Figure 1 ).

The values of the $b^{*}$ color parameter, which represents variation from blue to yellow, varied according to the treatment 
(from 18.49 to 21.61). Regression analysis indicated negative linear effect of extrusion temperature and negative quadratic effect of screw speed. The model cannot be used as a predictive model.

Therefore, the color parameters of the extrudates were mainly influenced by moisture level and cassava leaf flour percentage. Screw speed had no effect on the color of the extrudates. Similar result was observed by Razzaq et al. (2012).

Texture is an imperative attribute in consumer's observation of food and buying decision. Texture can be defined as the sensory expression for the structure of products in terms of their reaction to stress by the kinesthetic sense (Razzaq et al., 2012).

The hardness of the extruded products ranged from 10.92 to $45.99 \mathrm{~N}$ ( 1.11 to $4.69 \mathrm{kgf}$ ). Data analysis showed positive linear effect of temperature. The model was not significant.

\section{Conclusions}

Cassava leaf flour has several desirable attributes as an ingredient to produce extruded products. The extrusion process affected the physical characteristics of the extrudates. Moisture level and percentage of cassava leaf flour in the blends were the most important parameters affecting the dependent variables. Under conditions of low content of cassava leaf flour in the mixture of cassava flour, low moisture level, and intermediate values of extrusion temperature and screw speed it is possible to produce cassava-based snacks with desirable physical characteristics.

\section{Acknowledgments}

The authors are grateful for the financial support provided by the CNPQ - Brazil.

\section{References}

Allen, K. E., Carpenter, C. E., \& Walsh, M. K. (2007). Influence of protein level and starch type on an extrusion-expanded whey product. International Journal of Food Science \& Technology, 42(8), 953-960. http://dx.doi.org/10.1111/j.1365-2621.2006.01316.x

Altan, A., McCathy, K. L., \& Maskan, M. (2008). Twin-screw extrusion of barley-grape pomace blends: extrudate characteristics and determination of optimum processing conditions. Journal of Food Engineering, 89(1), 24-32. http://dx.doi.org/10.1016/j. jfoodeng.2008.03.025

Alves, R. M. L., \& Grossmann, V. E. (2002). Parâmetros de extrusão para produção de "snacks" de farinha de cará (Dioscoreaalata). Ciência e Tecnologia de Alimentos, 22(1), 32-38. http://dx.doi.org/10.1590/ S0101-20612002000100006

Anderson, R. A., Conway, H. F., Pfeifer, V. F., \& Griffin, J. R. L. (1969). Gelatinization of corn grits by roll and extrusion cooking. Cereal Science Today, 14(1), 4-11.

Arêas, J. A. G. (1992). Extrusion of food proteins. Critical Review in Food Science and Nutrition, 32(4), 365-392. PMid:1297326. http:// dx.doi.org/10.1080/10408399209527604

Camire, M. E., \& Krumhar, K. (1990). Chemical and nutritional changes in foods during extrusion. Critical Review in Food Science and Nutrition, 29(1), 35-57. PMid:2184829. http://dx.doi. org/10.1080/10408399009527513
Chavez, A. L., Bedoya, J. M., Sánchez, T., Iglesias, C., Ceballos, H., \& Roca, W. (2000). Iron, carotene, and ascorbic acid in cassava roots and leaves. Food \&Nutrition Bulletin, 21(4), 410-413.

Faubion, J. M., \& Hoseney, R. C. (1982). High temperature and short time; extrusion-cooking of wheat starch and flour. I. Effect of moisture and flour type on extrudate properties. Cereal Chemistry, 59(6), 529-533.

Food and Agriculture Organization of the United Nations - FAO. (2013). Cassava: a guide to sustainable production intensification. Rome: FAO. Retrieved from http://www.fao.org/docrep/018/i3278e/ i3278e.pdf

Howeler, R. H. (2012). Cassava leaf production for animal feeding. In R. H. Howeler (Ed.), The cassava handbook: a reference manual based on the Asian regional cassava training course, held in Thailand (pp. 626-648). Cali: CIAT.

Huber, G. (2001). Snack foods from cooking extruders. In E. W. Lusas \& L. W. Rooney (Eds.), Snack food processing (pp. 315-367). Boca Raton: CRC Press.

Mesquita, C. B., Leonel, M., \& Mischan, M. M. (2013). Effects of processing on physical properties of extruded snacks with blends of sour cassava starch and flaxseed flour. Food Science and Technology, 33(3), 404-410.

Moraru, C. I., \& Kokini, J. L. (2003). Nucleation and expansion duringextrusion and microwave heating of cereal foods. Comprehensive Reviews in Food Science and Food Safety, 2(4), 147163. http://dx.doi.org/10.1111/j.1541-4337.2003.tb00020.x

Oikonomou, N. A., \& Krokida, M. K. (2012). Water absorption index and water solubility index prediction for extruded food products. International Journal of Food Properties, 15(1), 157-168. http:// dx.doi.org/10.1080/10942911003754718

Razzaq, M. R., Anjum, F. M., Khan, M. I., Khan, M. R., Nadeem, M., Javed, M. S., \& Sajid, M. W. (2012). Effect of temperature, screw speed and moisture variations on extrusion cooking behavior of maize (Zea mays. L.). Pakistan Journal of Food Science, 22(1), 12-22.

Sagrilo, E., Vidigal-Filho O. S., Pequeno, M. G., \& Rimoldi, F. (2001). Quantificação e caracterização dos resíduos agrícolas de mandioca no estado do Paraná. In M. P. Cereda (Coord.), Agricultura: tuberosas amiláceas latino-americanas (pp. 413-434). São Paulo: Fundação Cargill.

Singh, B., Sekhon, K. S., \& Sing, N. (2007a). Effects of moisture, temperature and level of pea grits on extrusion behavior and product characteristics of rice. Food Chemistry, 100(1), 198-202. http:// dx.doi.org/10.1016/j.foodchem.2005.09.042

Singh, S., Gamlath, S., \& Wakeling, L. (2007b). Nutritional aspects of food extrusion: a review. International Journal of Food Science and Technology, 42(8), 916-929. http://dx.doi.org/10.1111/j.13652621.2006.01309.x

Statistical Analisys System Institute - SAS. (2004). SAS 9.1.2 qualification tools user's guide. Cary: SAS Institute.

StatSoft. (2004). Statistica 7.0 software. Tucksa: StatSoft, Inc.

Trombini, F. R. M., Leonel, M., \& Mischan, M. M. (2013). Desenvolvimento de snacks extrusados a partir de misturas de farinha de soja, fécula e farelo de mandioca. Ciência Rural, 43(1), 178-184. http://dx.doi.org/10.1590/S0103-84782012005000123

Yagci, S., \& Gogus, F. (2008). Response surface methodology for evaluation of physical and functional properties of extruded snack foods developed from food-by-products. Journal of Food Engineering, 86(1), 122-132. http://dx.doi.org/10.1016/j. jfoodeng.2007.09.018 